\title{
Reaction of erythrocyte membranes of animals on direct effects of infrasound
}

\author{
Sultan Tuleukhanov ${ }^{1}$, Zhanna Abdrassulova ${ }^{1,{ }^{*}}$, Yerubay Baibekov ${ }^{2}$, Bayan Toyzhigitova ${ }^{2}$, \\ and Rabiga Kaliyekper ${ }^{1}$ \\ ${ }^{1}$ Al-Farabi Kazakh National University, al-Farabi Ave. 71, 050040 Almaty, Republic of Kazakhstan \\ ${ }^{2}$ Khoja Akhmet Yassawi International Kazakh-Turkish University, B.Sattarkhanov Ave, 29, 161200 \\ Turkestan, Republic of Kazakhstan
}

\begin{abstract}
This study focuses on the reaction of the membranes of erythrocytes based on the principles that use direct effects of infrasound. The effect on biological features was investigated through the experiments on the rats. The work determined the level of electrical conductivity of blood in rats during direct, indirect and combined effects of infrasound in vivo. There was found that infrasound stimulate the immune system and therefore the results recommend that caution is take place for people who are dealing with these low frequencies. There was used many different technologies and methods, including total differential count in order to consider all of the nuances of the observed object and the main goal. The exposure to infrasound caused increase in the electric conductivity of whole blood than the control in both types of exposure which indicates a large increase of the surface charge density of erythrocyte resulted from the formation of highly reactive species such as superoxide radicals. There were found some undesired biological effects, however further work could have decreased them to a lesser extent.
\end{abstract}

\section{Introduction}

We live in a sea of sound, a motion. All life is vibration. Every atom is constantly moving, connecting us to everything in the universe, including our vital life force. Sound is vibrating force that affects each atom in our body. Infrasound is a vibrating force of low frequency $(0.0001-20 \mathrm{~Hz})$ with physical characters of strong penetration and less attenuation in long distance propagating. With the rapid development of modern industry and transport, more and more infrasound sources have been determined, which contribute to the dramatic increase of noise pollution in our environment $[1,2]$. The ability of infrasound to propagate over large distances contributes the possibility of adverse effects on living organisms. Particularly those in major industrial cities, used daily by subway, get a large dose of infrasound and subsonic vibrations are generated with fans, air conditioners, turbines, and so on. Features of the mechanisms of biological action of infrasound, their combined effect with other physical factors still inadequately studied community.

\footnotetext{
*Corresponding author: Zhanna.Abdrassulova@kaznu.kz
} 
During the 1970 's, infrasound was a popular topic within the scientific community.

The impact of infrasound on the individual and other environmental organisms has been studied insufficiently, but in most cases, it is negative [3]. Some studies focusing on biochemical, cellular, or morphological changes in organs and tissues. There were few studies evaluating reproductive functions, developmental effects, and immunological effects under the effect of infrasound in the same time studies that evaluated carcinogenic effects were little [4].

Considering the above- stated, and also, in view of absence of previous data on immunological, biophysical, electrical indicators on the rats blood, the influence of infrasonic waves in frequencies 15 Hertz with intensity in range $11 \mathrm{~dB}$ and also at various interval of times was planned to be carried in the present research dissertation.

The purpose was to study the mechanism of the effect of infrasound on the body of infrasound and its biological features

The subject of the research work is effect of infrasound on immunological, biophysical, bioelectrical, morphological indicators of rats' blood.

According to the literature on the problems of study, the effect of infrasound on biological objects has many contradictory facts 'about the features of reactions in human and animals in their impact. Infrasound is recognized as one of the most powerful physical environmental factors. Currently, in this investigation, we study the negative effects of infrasound and their mechanisms of action on living organisms, since it is a potent factor in the physical environment in addition to infrasound is used in practical medicine. Research work on this problem has not stopped and continued.

For the first time of exposure, it was observed the effect of infrasound waves on the immunological, biomechanical, bioelectrical properties of rats' blood after direct, indirect and combined exposure at various intervals of times. The effect of infrasound was on the general count of white blood cells, differential count of white blood cells (in term of myelocytes, young neutrophils, neutrophils, eosinophils, monocytes, basocytes, lymphocytes and shift index); the permeability of membranes of erythrocytes; The electrical conductivity of the blood membrane at $25^{\circ} \mathrm{C}$. Mechanisms of effect of infrasound on the cellular level show the damaging effects of infrasound on the cellular (violation of the permeability of erythrocyte membranes, changes in the electrical conductivity of blood, raising the total leukocyte blood counts, an increase of the shift index and leukocyte counts of blood). These changes indicate the level of deep structural and functional changes in erythrocyte membranes in the blood and immune indicators of organism. After 60 days of exposure morphological changes in rats were studied in the structures of white blood cells in normal conditions and after the direct, indirect and combined action of infrasound at different exposures of radiation, which showed that there is a direct violation at the cellular level. Also from obtained results it has showed that the effect of infrasound on the rates of hemolysis of red blood cell membrames of rats at different concentrations of $\mathrm{NaCl}(0.9 \%)$ in the case of direct, indirect and combined exposure. The impact of these infrasonic frequencies and intensities of exposure suppresses the natural resistance of the organism of experimental rats. The most informative indices to reduce the body's resistance are indicators of leukocytes, leukocyte formula, and the index shift.

Investigations were carried out according to standard methods specified in the text of the work. "Rats exposed to infrasound in an infrasonic radiator IFC-1 with sound fluctuations 15 $\mathrm{Hz}$ and with intensity $11 \mathrm{~dB}$. Standard techniques of experimental methods were applied to the immunological and morphological studies. Blood films were investigated and photographed using microscope with digital camera. The absolute count of red blood cells and shift index were recorded and calculated using of special mathematical formulas. The Level of hemolysis were determined by means of UV- Vis- Spectrophotometer, the percent of hemolysis was calculated using special mathematical formula and program for fitting data 
by using Sigmoidal and Gaussian The electrical conductivity was determined by means of 32000 function conductivity instrument ISTC Property K1117-15.

\section{Materials and methods}

\section{Infrasound facility exposure}

The model of infrasonic device that used in this work is IFS-1 Production Company TOO Batysmedtech, Uralsk (Kazakhstan). Range of radiated frequencies - from 13 to $30 \mathrm{~Hz}$. Relative error of established frequency no more $\pm 2 \%$. Level of sound pressure generated by installation is 10.9 to $14.0 \mathrm{~dB}$ at direct contact of a radiator to exposed animals. Installation works from a network of alternation current of frequency $50 \mathrm{~Hz}$ with rated voltage $220 \mathrm{~V}$ at a deviation of tension $10 \%$ from nominal value. Power consumption installation is no more than 160 wt. Establishment time of installation does not exceed 15 minutes after its inclusion [5]. In this work 650 male of albino rats, each of average weight $250 \pm 10$ gm were used. The animals were divided into 3 groups. Exposure to infrasonic waves for each group was carried out at different three-duration time 3,10, 20 minutes. The blood samples were collected from all animals before the exposure as self-control and after 3, 6, 12, 30 and 60 days.

Exposure to infrasonic waves for each group was carried out at different duration times 3, 10, 30, 60, 180, 600, 1800 and 3600 seconds. The blood samples were collected from all animals before the exposure as control and after the exposure.

The temperature inside the laboratory varied between $25^{\circ} \mathrm{C}$ and $27^{\circ} \mathrm{C}$. Lighting condition were natural light from large windows during the day and complete darkness during the night. Food was available (24 h/day).

Determination of the electric conductivity of blood. Bio-impedance, bioelectricity and the electrical properties of tissue are much about the same things. Bio-impedance (the ability to oppose (impede) electric current flow) deals with some passive electrical propperties of tissue. Bioelectricity deals with the ability of tissue to generate electricity, as for instance done by the heart (electrocardiography (ECG)). This electricity is endogenic means that, the tissue itself generates it. Bioelectricity is also, about how tissue can be controlled by electricity. Such electricity together with the electricity used for measuring bio impedance is exogenic (i. e. with externally applied electricity). Bioelectricity is about the electrical phenomena of life processes, and is a parallel to the medical subject electrophysiology. One basic mechanism is the energy consuming cell membrane ion pumps polarizing a cell, and the action potential generated if the cell is excited and ion channels open [6].

\section{Results and discussion}

Experimental investigations of the effect of infrasound on the permeability of erythrocyte membrane. Reaction of erythrocyte membranes of animals on direct effects of infrasound Results of the effect of infrasound on the permeability of erythrocytes membrane represented by hemolysis of red blood cells as well as the area under the curve, width at half maximum of the curve height of the Gaussian peaks. The direct exposure to infrasound was at different exposure times $(3,10,30,60,180,600,1800$, and 3600 seconds). As shown in table 1, a direct effect of infrasound on the hemolysis of red blood cells is dependent on the concentration of $\mathrm{NaCl}(0.9 \%)$ and exposure time of radiation. It was found that exposure to infrasound for (3, 10, 30, 60, 180, 600, 1800, and 3600 seconds) at different concentrations of $\mathrm{NaCl}(0.9 \%)$ leads to significant changes in hemolysis of erythrocyte membranes. Significant changes observed in the hemolysis of red blood cells membrane at concentration $45 \%$ of $\mathrm{NaCl}(0.9 \%)$ and at exposure time ( $3 \mathrm{sec}, 30 \mathrm{sec}, 180 \mathrm{sec}, 600 \mathrm{sec}, 1800 \mathrm{sec}$ and 3600 sec) At concentration $40 \%$ of $\mathrm{Nacl}(0.9 \%)$ and $(30 \mathrm{sec}, 60 \mathrm{sec}, 180 \mathrm{sec}, 600 \mathrm{sec}, 1800 \mathrm{sec}$ 
and $3600 \mathrm{sec})$; at $35 \%$ concentration of $\mathrm{NaCl}(0.9 \%)$ and $(60 \mathrm{sec}, 180 \mathrm{sec}, 600 \mathrm{sec}$ and 1800 $\mathrm{sec})$ were significant changes. At concentration $0 \%$ of $\mathrm{NaCl}(0.9 \%)$, lead to $100 \%$ hemolysis of red blood cells membrane at all period of exposure. It's found that a clear maximum hemolysis of erythrocyte occurred at concentrations $50 \%, 45 \%$ and $40 \%$ of $(0.9 \%) \mathrm{NaCl}$, and the minimum hemolysis occurred at concentrations of $100 \%$ and $60 \%$.

Table 1. The Percent of hemolysis of red blood cell membranes at different concentrations of $\mathrm{NaCl}$ $(0.9 \%)$ before and after direct exposure to infrasound for different times of exposure (Group A).

\begin{tabular}{|c|c|c|c|c|c|c|c|c|}
\hline \multirow{3}{*}{$\begin{array}{l}\text { Time exposure } \\
(\mathrm{sec})\end{array}$} & \multicolumn{8}{|c|}{ Hemolysis of red blood cells at different concentrations of $\mathrm{NaCl}(0.9 \%)$} \\
\hline & $100 \%$ & $60 \%$ & $55 \%$ & $50 \%$ & $45 \%$ & $40 \%$ & $35 \%$ & $0 \%$ \\
\hline & $\begin{array}{c}\text { Mean } \pm \\
\text { SE }\end{array}$ & $\begin{array}{c}\text { Mean } \pm \\
\text { SE }\end{array}$ & $\begin{array}{l}\text { Mean } \\
\pm \mathrm{SE}\end{array}$ & $\begin{array}{l}\text { Mean } \\
\pm \mathrm{SE}\end{array}$ & $\begin{array}{l}\text { Mean } \\
\pm \text { SE }\end{array}$ & $\begin{array}{l}\text { Mean } \\
\pm \mathrm{SE}\end{array}$ & $\begin{array}{l}\text { Mean } \\
\pm \mathrm{SE}\end{array}$ & $\begin{array}{l}\text { Mean } \\
\pm \text { SE }\end{array}$ \\
\hline Control & $\begin{array}{c}2.75 \pm \\
0.47\end{array}$ & $\begin{array}{c}3.02 \pm \\
0.73\end{array}$ & $\begin{array}{c}4.56 \pm \\
0.71\end{array}$ & $\begin{array}{c}9.28 \pm \\
1.58 \\
\end{array}$ & \begin{tabular}{|l|}
$32.01 \pm$ \\
1.22 \\
\end{tabular} & $\begin{array}{c}49.55 \pm \\
1.98\end{array}$ & $\begin{array}{c}79.34 \pm \\
1.58 \\
\end{array}$ & $\begin{array}{c}100.00 \pm \\
0.00\end{array}$ \\
\hline 3 & $\begin{array}{c}4.79 \pm \\
0.13 * * *\end{array}$ & $\begin{array}{c}6.12 \pm \\
0.15 * * *\end{array}$ & \begin{tabular}{|c|}
$6.98 \pm$ \\
$0.25^{* * * *}$
\end{tabular} & $\begin{array}{c}13.35 \pm \\
1.00 *\end{array}$ & \begin{tabular}{|c|}
$22.34 \pm$ \\
$2.50^{*}$
\end{tabular} & $\begin{array}{c}43.82 \pm \\
2.50\end{array}$ & $\begin{array}{c}77 \pm 40+ \\
3.00\end{array}$ & $\begin{array}{c}100.00 \pm \\
0.00\end{array}$ \\
\hline 10 & $\begin{array}{c}3.89 \pm \\
0.13 * * *\end{array}$ & $\begin{array}{c}4.75 \pm \\
0.15 * * *\end{array}$ & $\begin{array}{l}5.76 \pm \\
0.25 *\end{array}$ & $\begin{array}{l}14.10 \pm \\
1.00^{* *}\end{array}$ & \begin{tabular}{|c}
$28.14 \pm$ \\
2.50
\end{tabular} & $\begin{array}{c}56.30 \pm \\
2.50\end{array}$ & $\begin{array}{c}83.84 \pm \\
3.00\end{array}$ & $\begin{array}{c}100.00 \pm \\
0.00\end{array}$ \\
\hline 30 & $\begin{array}{c}3.12 \pm \\
0.13 \\
\end{array}$ & $\begin{array}{c}3.22 \pm \\
0.15 \\
\end{array}$ & $\begin{array}{c}3.94 \pm \\
0.25 \\
\end{array}$ & $\begin{array}{c}1.77 \pm \\
1.00 * * *\end{array}$ & $\begin{array}{l}15.11 \pm \\
2.50^{* * * *}\end{array}$ & $\begin{array}{c}31.00 \pm \\
2.50 * * *\end{array}$ & \begin{tabular}{|l}
$71.92 \pm$ \\
3.00 \\
\end{tabular} & $\begin{array}{c}100.00 \pm \\
0.00\end{array}$ \\
\hline 60 & $\begin{array}{c}2.25 \pm \\
0.13 \\
\end{array}$ & $\begin{array}{c}2.54 \pm \\
0.15 \\
\end{array}$ & $\begin{array}{c}5.35 \pm \\
0.25 \\
\end{array}$ & $\begin{array}{c}10.74 \pm \\
1.00 \\
\end{array}$ & \begin{tabular}{|c|}
$30.07 \pm$ \\
2.50 \\
\end{tabular} & $\begin{array}{l}59.62 \pm \\
2.50 * \\
\end{array}$ & $\begin{array}{l}92.40 \pm \\
3.00 * * \\
\end{array}$ & $\begin{array}{c}100.00 \pm \\
0.00 \\
\end{array}$ \\
\hline 180 & $\begin{array}{c}2.96 \pm \\
0.13\end{array}$ & $\begin{array}{l}3.61 \pm \\
0.15\end{array}$ & $\begin{array}{c}3.71 \pm \\
0.25\end{array}$ & $\begin{array}{c}7.50 \pm \\
1.00\end{array}$ & $\begin{array}{l}13.70 \pm \\
2.50^{* * *}\end{array}$ & \begin{tabular}{|c|}
$30.72 \pm$ \\
$2.50 * * *$
\end{tabular} & $\begin{array}{l}62.82 \pm \\
3.00^{* * *}\end{array}$ & $\begin{array}{c}100.00 \pm \\
0.00\end{array}$ \\
\hline 600 & $\begin{array}{c}3.15 \pm \\
0.13\end{array}$ & $\begin{array}{c}3.32 \pm \\
0.15\end{array}$ & $\begin{array}{c}3.65 \pm \\
0.25 \\
\end{array}$ & $\begin{array}{l}5.53 \pm \\
1.00^{*} \\
\end{array}$ & $\begin{array}{r}12.47 \pm \\
2.50 * * *\end{array}$ & $\begin{array}{c}27.20 \pm \\
2.50 * * * \\
\end{array}$ & $\begin{array}{l}64.03 \pm \\
3.00 * * \\
\end{array}$ & $\begin{array}{c}100.00 \pm \\
0.00 \\
\end{array}$ \\
\hline 1800 & $\begin{array}{c}2.74 \pm \\
0.13 \\
\end{array}$ & $\begin{array}{c}2.83 \pm \\
0.15\end{array}$ & $\begin{array}{l}3.20 \pm \\
0.25^{*}\end{array}$ & \begin{tabular}{|c|}
$4.66 \pm$ \\
$1.00^{* * *}$
\end{tabular} & $\begin{array}{c}12.45 \pm \\
2.50^{* * * *}\end{array}$ & $\begin{array}{c}27.11 \pm \\
2.50 * * *\end{array}$ & $\begin{array}{l}55.49 \pm \\
3.00^{* * *}\end{array}$ & $\begin{array}{c}100.00 \pm \\
0.00\end{array}$ \\
\hline 3600 & $\begin{array}{c}3.01 \pm \\
0.13 \\
\end{array}$ & $\begin{array}{c}3.17 \pm \\
0.15\end{array}$ & $\begin{array}{c}3.95 \pm \\
0.25\end{array}$ & $\begin{array}{l}5.46 \pm \\
1.00^{*}\end{array}$ & $\begin{array}{l}11.69 \pm \\
2.50^{* * *}\end{array}$ & \begin{tabular}{|c|}
$39.74 \pm$ \\
$2.50 * * * *$
\end{tabular} & $\begin{array}{c}76.53 \pm \\
3.00 \\
\end{array}$ & \begin{tabular}{|c}
$100.00 \pm$ \\
0.00
\end{tabular} \\
\hline One way ANO & & & & & & & & \\
\hline F-ratio & 14.35 & 15.86 & 13.57 & 14.77 & 12.31 & 26.09 & 15.90 & - \\
\hline P-value & $0.00 * * *$ & $0.00 * * *$ & $\begin{array}{l}0.00 * \\
* *\end{array}$ & $\begin{array}{l}0.00^{*} \\
* *\end{array}$ & $\begin{array}{l}0.00^{*} \\
* *\end{array}$ & $\begin{array}{c}0.00 * \\
* *\end{array}$ & $\begin{array}{c}0.00 * \\
* *\end{array}$ & $\begin{array}{c}0.00 * * \\
*_{-}\end{array}$ \\
\hline
\end{tabular}

The results suggested that the time factor of exposure to infrasound, with the concentration of $\mathrm{NaCl}(0.9 \%)$ might significantly affect erythrocyte membranes in response to the direct effects of infrasound. It's found that changes in the rate of hemolysis of erythrocyte membranes after effects of infrasound is most pronounced on the concentration $\mathrm{NaCl}(0.9 \%)$ and the exposure time of radiation, the reliability of the data is $\mathrm{P}<0.05 ; \mathrm{P}<$ 0.01 and $\mathrm{p}<0.001$. Figure 1 shows the hemolysis of red blood cell membranes in control and experimental groups of animals on the concentration of $\mathrm{NaCl}(0.9 \%)$ at different ent exposure times of infrasound. From the figure, 1 that represent the relation between percent of hemolysis and the concentration of $\mathrm{NaCl}(0.9 \%)$ showed a clear relationship but it depends on the exposure time of radiation to infrasound. The results obtained in experimental group strikingly reproved by those in control groups.

Exposures to infrasound for $30 \mathrm{sec}, 180 \mathrm{sec}, 600 \mathrm{sec}, 1800 \mathrm{sec}$ and $3600 \mathrm{sec}$ recorded inverse relationship, ie, indicators of hemolysis (in\%) in the experimental groups are lower than in the control groups of animals. 

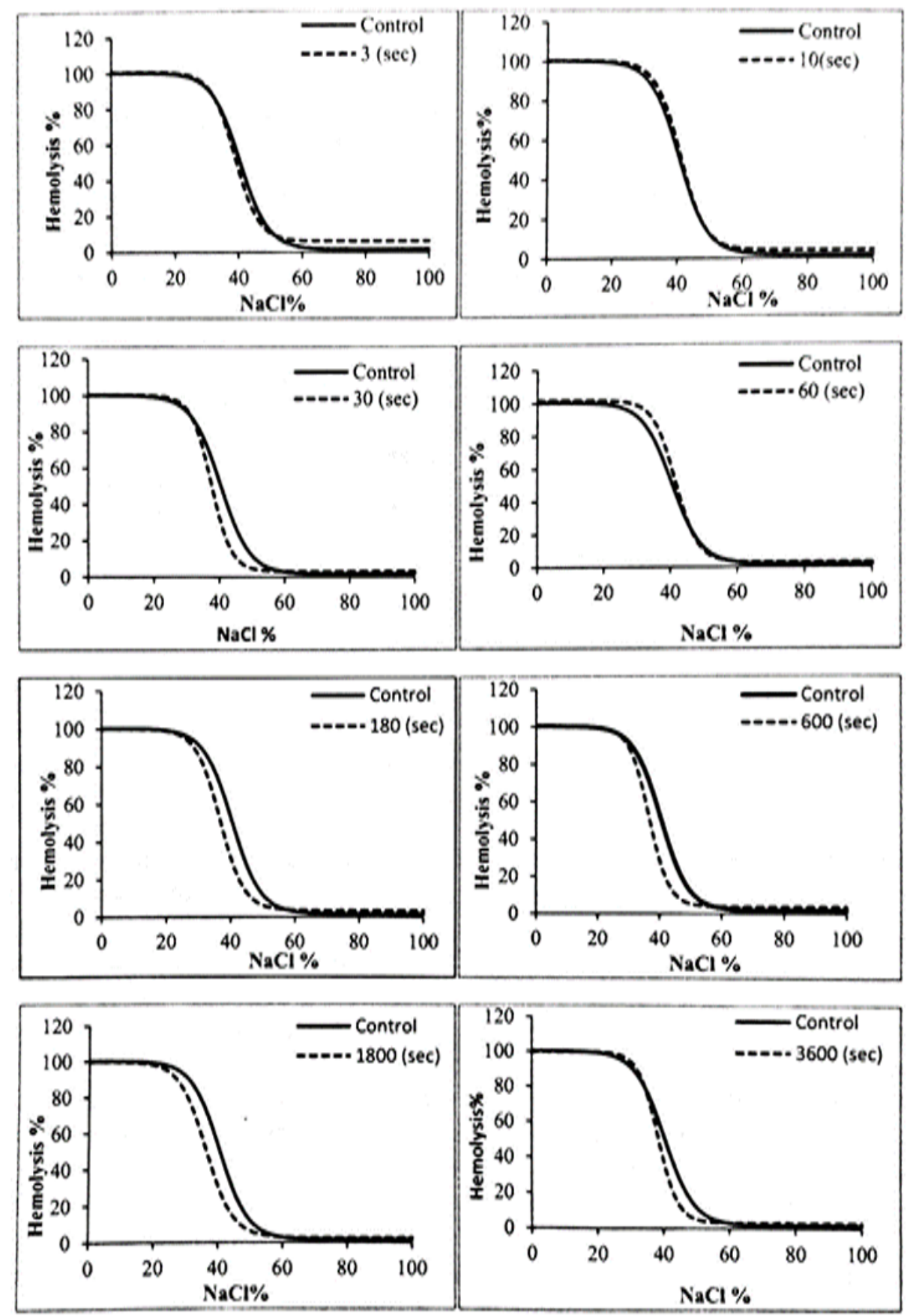

Fig. 1. Hemolysis curves of red blood cell membranes at different concentrations of $\mathrm{NaCl}$ $(0.9 \%)$ before and after direct exposure to infrasound for different periods of exposure (Group A) 

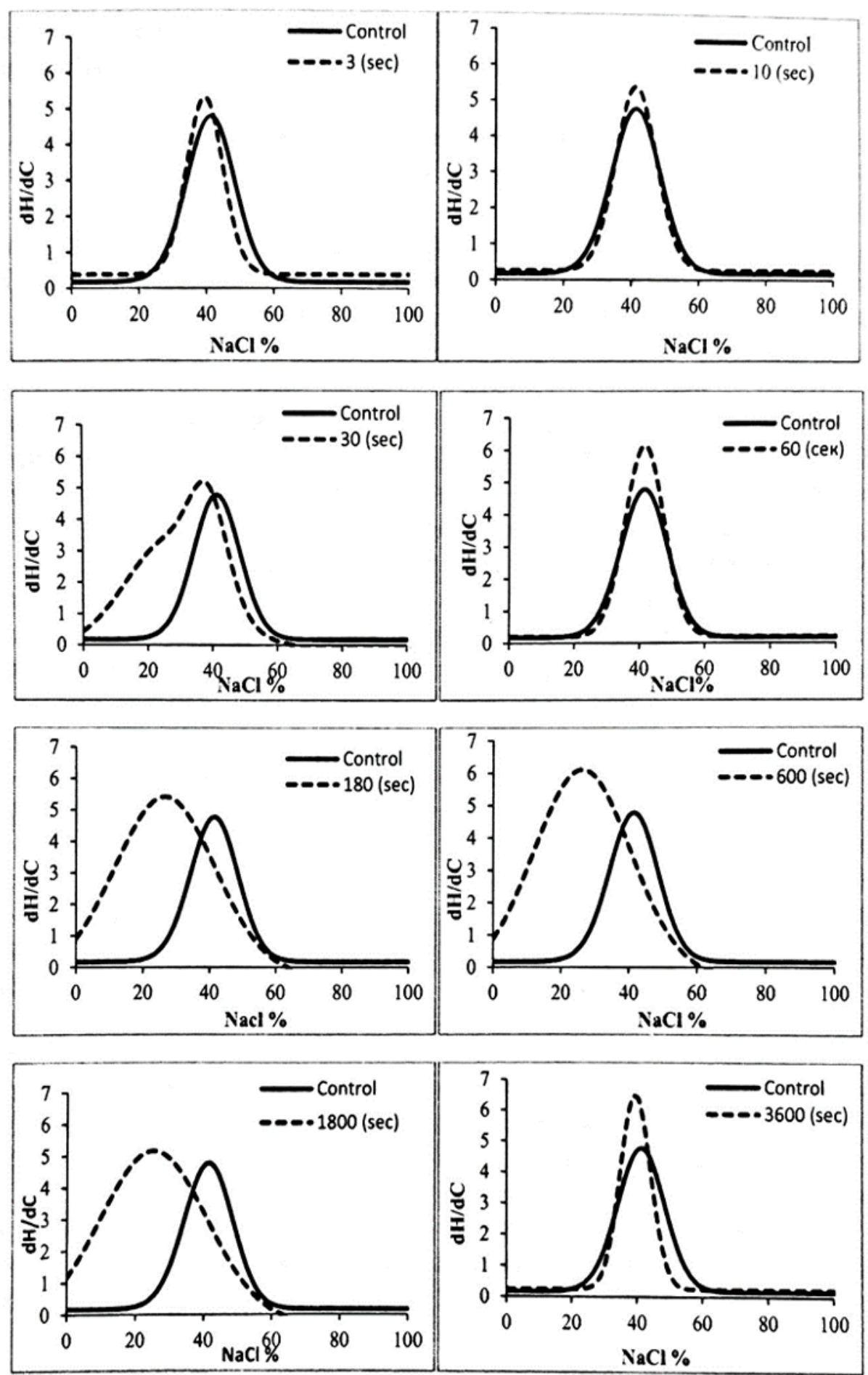

Fig. 2. The rate of hemolysis versus $\mathrm{NaCl}(0.9 \%)$ for controland different periods of exposure for group A. 
Table 2 presents the area, height and width of the Gaussian curves, and Hso- $(\mathrm{NaCl}$ concentration that produce $50 \%$ hemolysis of red blood cell membranes) as a function in exposure times to infrasound.

Table 2. Area, Width, Height and H50 of the Gaussian peaks for control and after different periods of exposure for group A.

\begin{tabular}{l|l|l|l|l}
\hline \multirow{2}{*}{$\begin{array}{l}\text { Time } \\
(\mathrm{sec})\end{array}$} & Area & Width & Height & $\mathrm{H}_{50}$ \\
\cline { 2 - 5 } Control & Mean $\pm \mathrm{SE}$ & Mean $\pm \mathrm{SE}$ & Mean $\pm \mathrm{SE}$ & Mean $\pm \mathrm{SE}$ \\
\hline 3 & $83.0 \pm 4.9$ & $14.4 \pm 1.3$ & $4.6 \pm 0.1$ & $40.4 \pm 0.1$ \\
\hline 10 & $66.7 \pm 4.2$ & $10.8 \pm 0.7$ & $4.9 \pm 0.0$ & $38.8 \pm 0.5^{*}$ \\
\hline 30 & $77.4 \pm 4.5$ & $12.0 \pm 0.5$ & $5.1 \pm 0.1$ & $40.8 \pm 0.5$ \\
\hline 60 & $158.9 \pm 81.4$ & $19.6 \pm 8.4$ & $6.2 \pm 0.7^{* *}$ & $37.6 \pm 0.4^{* * *}$ \\
\hline 180 & $89.4 \pm 4.3$ & $12.0 \pm 0.4$ & $5.9 \pm 0.1^{* *}$ & $41.4 \pm 0.4$ \\
\hline 600 & $215.0 \pm 4.9^{* *}$ & $30.1 \pm 0.3^{* *}$ & $5.7 \pm 0.2^{*}$ & $36.7 \pm 0.5^{* * *}$ \\
\hline 1800 & $228.7 \pm 6.6^{* *}$ & $28.5 \pm 0.2^{* *}$ & $6.4 \pm 0.2^{* * *}$ & $36.6 \pm 0.4^{* * *}$ \\
\hline 3600 & $214.4 \pm 3.9^{* *}$ & $31.2 \pm 0.4^{* *}$ & $5.5 \pm 0.2^{*}$ & $35.7 \pm 0.5^{* * *}$ \\
\hline One way ANOVA & $72.6 \pm 1.8$ & $9.3 \pm 0.2$ & $6.3 \pm 0.0^{*}$ & $38.4 \pm 0.4^{* *}$ \\
\hline F-ratio & 6.41 & 9.91 & 6.05 \\
\hline P-value & $0.01^{* *}$ & $0.00^{* * *}$ & 24.58 \\
\hline Where - $* \mathrm{P} \leq 0.05 ; * * \mathrm{P} \leq 0.01 ; * * \mathrm{P} \leq 0.0001$ & $0.01^{* *}$ \\
\hline
\end{tabular}

The results show that, the area of Gaussian curves in experinental groups of animals differ from those in the control group and depends on the exposure time of irradiation significant results were found in the exposures for $180 \mathrm{~s}, 600 \mathrm{~s}$ and $1800 \mathrm{~s}(\mathrm{P}<0.01)$ and value ranged from $66.7 \pm 4.2228 .7$ 6.6. A full width at half maximum of Gaussian curve in the experimental groups has a similar results and recorded significant value $(\mathrm{P}<0.01)$ that ranged between $9.3=0.2$ up to $31.2=0.4$.

The height of Gaussian curves depends more closely on the irradiation time, so significant changes in the experimental groups, compared to the control recorded at $3030 \mathrm{sec}$ exposures, 60 seconds $(\mathrm{P}<0.01), 180 \mathrm{sec}(\mathrm{P}<0.05), 600 \mathrm{sec}(\mathrm{P}<0.001), 1800$ second and 3600 seconds $(\mathrm{P}<0.05)$ and varied in the range $4.9 \pm 0.06 .40 .2$. The value of Hso- $(\mathrm{NaCl}$ concentration which produce $50 \%$ hemolysis of red blood cell membranes) recorded significant changes, for example, 3 seconds (P 0.05), $30 \mathrm{~s}, 180 \mathrm{~s}, 600 \mathrm{~s}, 1800 \mathrm{~s}(\mathrm{P}<0.001)$, and at $3600 \mathrm{sec}(\mathrm{P}<$ $0.01)$ and fluctuated between $35.70 .5+41.4 \pm 0.4$. Figure 2, illustrates the relationship of the differential rate of hemolysis of erythrocyte membranes as a function of $\mathrm{NaCl}(0.9 \%)$ for groups irradiated with an infrasound from 3 to 3600 seconds. From these results, it is clear that the differential rate of hemolysis of erythrocyte membranes in experimental groups of animals differ from those in the control groups. Thus, significant changes in differential rates of hemolysis observed at exposure to 30 seconds, 180 seconds, 600 seconds and 1800 seconds, and non-significant changes observed at $3 \mathrm{sec}, 10 \mathrm{sec}, 60 \mathrm{sec}$ and $3600 \mathrm{sec}$.

Therefore, we can concluded that the value of differential parameters of hemolysis of red blood cell both in control and experimental animals depending on the concentration of $\mathrm{NaCl}$ $(0.9 \%)$ and radiation time of exposure to infrasound.

According to the obtained results, we can conclude the following: a study of the permeability of erythrocyte membranes allow us to establish the changes that occur in the membrane when exposed to infrasound, and which revealed significant dependence on the 
concentration of $\mathrm{NaCl}(0.9 \%)$ and the exposure time of radiation. The results also suggest that the mechanism of the harmful influence of the factor has an important role in primary damage in the structure and function of cell membranes. A common structure of erythrocyte membranes and cell membranes of other cells allows to assume that the mechanism of action of infrasound on the body has enough universal significance, certainly, taking into account the specific features of the structure of cell membranes of various organs and systems.

Thus, we first identified characteristics of permeability of erythrocytes membrane and the parameters which may related to them as hemolysis of red blood cells, area under the curve, width of the curve at half maximum, height of the Gaussian peaks and (H50).

The permeability of erythrocyte membrane was determined by measuring the degree of hemolysis in a mixture of isotonic solutions of urea $(18 \mathrm{~g} / \mathrm{L})$ and $\mathrm{NaCl}(0.9 \mathrm{~g} / 100 \mathrm{~mL})$. Urea has the ability to penetrate quickly through a cellular membrane and to create inside the erythrocyte a hyperosmotic medium, which leads to swelling of the erythrocyte, infringement of the integrity of the cell membrane and leakage of hemoglobin [7]. From the results of the permeability of red blood cells, it is shown that: the permeability of erythrocyte membranes under direct, indirect and combined effect of infrasound had clearly increased the percent of hemolysis; the rate of hemolysis and the maximum rate of hemolysis of erythrocyte membrane. The results reflect the increase in the fragility of the membrane of erythrocytes as well as the abnormal increase in the membrane elasticity.

The cell membrane potential helps control cell membrane permeability. The obtained data are in agreement with [8] who reported that exposure to $8 \mathrm{~Hz}$ at 100 and $140 \mathrm{~dB}$ for up to 25 days affected conjunctival blood vessels. Capillaries initially constricted and an increased permeability of blood vessels led to capillary and tissue swelling [9,10] reported also that exposures of 8 and $16 \mathrm{~Hz}$ at $140 \mathrm{~dB}$ will led to ruptured of blood vessel walls and destroyed acini, this may be due to increase of oxidative stress produced by the noise stress [11]. Many studies showed that several parameters of red blood cells functions and integrity are negatively affected by increased oxidative stress. Oxidative stress is responsible for hemolysis and induced activation of an enzyme directly involved in energy metabolism whose regulation might closely be related to the maintenance of cell integrity that may be lead to changes o erythrocyte membrane ionic permeability [12-14]

In our research it's shown that the electric conductivity has higher values than the control in all types of exposure which indicates a large increase of the surface charge density of erythrocyte resulted from the formation of highly reactive species such as superoxide radicals $\left(20^{*}\right)$, hydrogen peroxide $(\mathrm{H} 2 \mathrm{O} 2)$, hydroxyl radicals $\left(\mathrm{OH}^{*}\right)$ and lipid peroxides (LPO)]. This may be interpreted by most of the molecules in the body are electrical dipoles. These dipoles electronically function like transducers in that they are able to turn acoustic waves into electrical waves and electrical waves into acoustic waves and the natural properties of bio molecular structures enables cell components and whole cells to oscillate and interact resonantly with other cells [15-17].

Based on the obtained results of electric conductivity of red blood cells it can be concluded that the exposure to infrasound at $15 \mathrm{~Hz}$ with intensity $11 \mathrm{~dB}$ cause continuous increase in the electric conductivity of red blood cells until it reached maximum increase after exposure to 600 seconds (10 minutes). The electric conductivity decreased after 1800 seconds (30 minutes) and again started to increase until reached maximum increase at 3600 seconds (60 $\mathrm{min})$.

\section{Conclusion}

Based on the obtained results from the carried experiments it can be concluded that: 
1. The exposure to infrasound caused increase in the electric conductivity of whole blood than the control in both types of exposure which indicates a large increase of the surface charge density of erythrocyte resulted from the formation of highly reactive species such as superoxide radicals $(2 \mathrm{O}-\bullet)$, hydrogen peroxide $(\mathrm{H}, \mathrm{O} 2)$, hydroxyl radicals $\left({ }^{\circ} \mathrm{OH}\right)$ and lipid peroxides (LPO). This may be interpreted by most of the molecules in the body are electrical dipoles. These dipoles electronically function like transducers in that they are able to turn acoustic waves into electrical waves and electrical waves into acoustic waves and the natural properties of bio molecular structures enables cell components and whole cells to oscillate and interact resonantly with other cells.

2. Comparative analysis of immunological parameters, the permeability of erythrocyte membranes and the electrical conductivity of blood in rats under the effects of infrasound at a frequency of $15 \mathrm{~Hz}$ and intensity $11 \mathrm{~dB}$ through exposure time of 3-3600 seconds allowed proving that infrasound causes nonspecific changes at the cellular and subcellular levels of the organism.

3. The obtained results strength the hypothesis that the mechanical energy of infrasound was absorbed and turned into biochemical energy in the blood, which created reactive species leaded to disturbance in the transcription of ions inside and outside the cell and therefore change occurred in the electric conductivity and permeability of red blood cells.

4. Although of undesired biological effects of infrasound that detected through our study, still there are many others beneficial effects should be taken in our consideration. Many hospitals around the world used infrasound in the treatment of diseases diseases but it should be taken into account using frequency, time of exposure and intensity to avoid the expected harmful effects after exposure to these waves.

5. Finally we recommended that many high quality researches needed to understand the way of interaction of infrasound with biological systems and to establish the standers of exposure from this wave.

\section{References}

1. O. Backteman, J. Kohler, L. Sjoberg, Low Freq. Noise Vib., 3, 96-112 (1984)

2. Z.Q. Zhuang, Z.H. Pei, J.Z. Chen, Dis. Control Prev., 9, 328-329 (2005)

3. D. Guzas, R. Virsilas, Ultragarsas (Ultrasound), 64 (3), 34-37 (2009)

4. C.B. Karen, M. Claudine, E.D. Elizabeth, Infrasound Toxicological Summary, (2001).

5. O.A. Kazakov, Treatment by an infrasound and its other possibilities, 142 (1999)

6. G. Sverre, G.M. Orjan, Bio impedance and bioelectricity (Elsevier Linacre House, Jondan Hill, Oxford, 2008)

7. V.N Kolmakova, V.G. Radchenko, TherAch, 54, 59-62 (1982)

8. V.I. Svidovyi, V.N. Kolmakov, G.V. Kuznetsova, Gig. Sanit, 10, $73-74$ (1985)

9. V.I. Svidovyi, O.I. Kuklina, Gig. Tr. Prof. Zabol, 6, 51-100 (1985)

10. A.S. Nekhoroshev, Vestn. Otorinolaringol, 6, 120 (1985)

11. D. Reha, M. Hakan, Y. Hasan, U. Kagan, A. Abdullah, A. Muzaffer, G. Abdurrahman, U. Ramazan, D. Mevlut, Eur J Gen Med, 6, 20-24 (2009)

12. I. Maridonneau, P. Braquet, R.P. Garay, J. Biol. Chem, 258, 3107-3113 (1983)

13. N. Wang, De. Ingber, Biophys J., 66, 2181-6812 (1994)

14. R. Pekar, Percutaneous Bio-Electrotherapy of Cancerous Tumours: A documentation of Basic Principles and Experiences with Bio-Electrotherapy (Biophys J., Munich, Germany 2008)

15. J.B. Beal, Biosystems liquid crystals \& potential effects of nanaral \& artiflicial electromagnetic (St Manis's Press, New York 1996)

16. S.G. Gaidin, V.P. Zinchenko, I.Y. Teplov, S.T. Tuleukhanov, A.M. Kosenkov, Epilepsy Research, 158, 106224 (2019) 
17. I.Y. Teplov, S.T.Tuleukhanov, V.P. Zinchenko, Biophysics (Russian Federation), 63(4), 566-575 (2018) 